\title{
Knowledge management, sharing, and transfer in cross-national teams and the remote management of team members: The onsite-offshore phenomenon of service EMNEs
}

Parth Patel, Hussain G. Rammal *, João J. Ferreira, Verma Prikshat

*Corresponding Author

Accepted for publication in Journal of Global Mobility on 24 July 2021

https://doi.org/10.1108/JGM-03-2021-0020

\begin{abstract}
Purpose - This study examines how emerging market multinational enterprises operating in the service sector manage knowledge and team members in their overseas subsidiaries and what role expatriates play in their operations.

Design/methodology/approach - We use a multiple case study design and interview 20 senior managers representing 16 Indian IT firm's subsidiaries in Australia. The onsite-offshore concept and the SECI model are used to explain the knowledge management process.

Findings - The findings show that Indian IT firms mostly transfer knowledge from their headquarters in the parent country to their subsidiaries in the host country using the onsiteoffshore model where work is divided and coordinated between team members situated between the two locations. Furthermore, the host country subsidiaries have limited independence in decision-making due to a forward, one-way diffusion of knowledge, thus limiting a two-way interaction between the HQ and the subsidiary for opportunities to create and exchange new knowledge.
\end{abstract}

Originality/Value - The study is one of the few to investigate the onsite-offshore phenomenon in service-based emerging market multinational enterprises.

Keywords: Emerging market multinational enterprise, Globally distributed teams, Service industry, Knowledge management, Information technology, India 


\section{Knowledge management, sharing, and transfer in cross-national teams and the remote management of team members: The onsite-offshore phenomenon of service EMNEs}

There is broad consensus that the competitive advantage for technology firms resides in the knowledge held by their employees (Brymer, Boss, Uhlenbruck, \& Bierman, 2020). Organizations need to find ways to manage, share, and transfer this tacit knowledge held by individuals (Guo, Jasovska, Rammal, \& Rose, 2020). There is a substantial body of research that looks at multinational enterprises (MNEs) and their evolution into globally integrated networks (Salk \& Brannen, 2000) with distributed and transnational teams spanning across multiple geographic, physical, and cultural boundaries (Connaughton \& Shuffler, 2007; Earley \& Gibson, 2002; Lagerström \& Andersson, 2003; Schweiger, Atamer, \& Calori, 2003). Given this backdrop, there is growing academic interest in learning about the MNEs' use of globally distributed networks using cross-national teams and remote teams to manage their foreign operations in host countries (Goodall \& Roberts, 2003; Hinds, Liu, \& Lyon, 2011).

Despite the growing scholarly interest, our understanding of how MNEs use globally distributed work and cross-national teams is limited due to a lack of contextualized understanding surrounding this issue. While this process is challenging in all organizations, it is more difficult when the individuals are dispersed globally across national boundaries, with physical distance becoming a barrier to the transfer of the core organizational culture values, processes, and expectations. Although virtual teams are often described as an option for undertaking cross-border activities, previous studies suggest that the interaction between individuals working physically together can be more effective in facilitating the exchange of ideas and knowledge sharing (O’Higgins, Andreeva \& Aramburu, 2021).

For MNEs, expatriation is often used to transfer knowledge and translate the tacit knowledge into an explicit form (Harzing, Pudelko, \& Sebastian Reiche, 2016; Minbaeva \& Michailova, 2004; Riusala \& Suutari, 2004). These individuals possess managerial and/or technical knowledge, and the expatriation process can facilitate the interaction and engagement between the expatriates and the host-country nationals. The expatriation process and the management, sharing, and transfer of knowledge is not without their challenges. However, the majority of the literature focuses on developed and Western MNEs operating in emerging markets (EMs), limiting our understanding of the knowledge management and transfer process employed by emerging market multinational enterprises (EMNEs) (Kong, Ciabuschi, \& Martín, 2018). The limited insights from EMNEs, especially those with subsidiaries in developed economies, restrict our understanding of the challenges they face and the strategies they employ that other MNEs could apply. Hence, we are yet to have a holistic understanding of global knowledge management challenges.

These issues are especially pertinent in organizations operating in the service sector, such as information technology (IT) firms whose primary asset is the knowledge held by the employees. For service sector MNEs, using and managing this tacit knowledge across their global network is critical in their success and competitive position in the industry (Mehreen, Rammal, Pereira, \& Del Giudice, 2021). The ethnocentric view of knowledge being generated and transferred from developed economies no longer holds sway. However, the business management literature has yet to explore in detail the processes by which EMNEs transfer knowledge across the inter-and intra-organizational networks and the challenges they face in this endeavor. Inspired by this gap in the extant literature, this study attempts to address the following research questions: 
RQ2) How do EMNEs remotely manage team members, and what is the role of expatriates in these firms?

This study focuses on how service EMNEs manage, share, and transfer knowledge to their operations in developed countries within the intra-organizational global network. We explore the role of globally distributed work and cross-national teams in Indian information technology (IT) MNEs. Applying the multiple case study approach, we interviewed 20 senior executives from 16 Indian IT firms' subsidiaries in Australia. The findings suggest that Indian MNEs are born-global firms that effectively use their highly skilled, flexible, and low-cost, talented expatriate labor pool from their parent country operations and combine it with their onsiteoffshore business model to transfer home country knowledge to their international subsidiaries in developed countries to deliver IT service to their local customers and to achieve global competitive advantages for business growth.

The study makes key theoretical and practical contributions. Guided by the onsite-offshore concept and the SECI model, we compare the findings of our study with previous studies and theories about the knowledge transfer process in organizations. Our findings suggest that EMNEs do not follow all the stages of knowledge transfer process identified in previous studies, and we find evidence of knowledge hording at the headquarters. We also find that the onsite-offshore arrangement, in which the expatriate is expected to play a significant role in the knowledge transfer process, is not utilized in an effective manner in EMNEs. The process remains unfulfilled as there is only one-way knowledge sharing and the communication is exclusively between headquarters staff and the expatriate. This reduced absorption of new knowledge from the host-country can affect the competitiveness of EMNEs and their future profitability.

The next section of this article reviews the literature on global mobility and knowledge management in MNEs. This is following by the research methodology section, which discusses the multi-case study method adopted for this study, its research setting of Indian IT firms, the data collection procedures followed, and the analytical techniques employed. The section that follows analyzes the empirical data from the interviews and presents the findings. And, the final section provides a discussion of the findings, including the theoretical and practical implications of this study, followed by the conclusion.

\section{Global mobility, cross-national teams, and knowledge management in MNEs}

The transfer of knowledge across an MNE's global network continues to be a significant stream of research in the international business and international human resource management literature. Using knowledge as an organizational resource can help firms gain a competitive advantage (Mudambi \& Navarra, 2004). Baumard (1999) argues that an organization's primary function is to generate knowledge, and firms need to have processes that support the identification, generation, and leveraging of new and existing knowledge sources.

Knowledge can be classified into two: explicit and tacit. Explicit knowledge can be described as information found in a physical form (written, audio-visual, etc.) that is easy to understand, transfer, and replicate. Tacit knowledge, on the other hand, is the knowledge that individuals hold. It exists in an intrinsic form and is difficult to transfer. Service firms do not have the 
physical assets that require explicit knowledge transfer. Instead, they rely on the tacit knowledge held by the individuals in the firm. So, how can firms facilitate the transfer of tacit knowledge?

Nonaka and Takeuchi's (1995) SECI model is widely used in the knowledge management literature and explains how the knowledge creation and transfer process takes place through four stages of socialization, externalization, combination, and internalization. First, the socialization process is facilitated through individuals' direct interactions, such as formal and informal discussions, working together in groups, or other social engagements and interactions. By observing and discussing how individuals work, others can learn and attempt to replicate the steps and processes they follow. The next stage of the model states that this new knowledge gained in the socialization process needs to be externalized by articulating knowledge into words and translating them into documents (Nonaka \& Takeuchi, 1995).

Collating relevant internal and external forms of explicit knowledge and converting it into a more usable form involves the process called combination. The resulting knowledge is communicated and transferred in an explicit condition to members within the organization. The final step of the process involves ensuring that the explicit knowledge now available to individuals in the organization is understood and applied in the process they follow. Hence, this explicit knowledge now takes on a tacit form through internalization (Nonaka \& Takeuchi, 1995). This process involves transferring the explicit knowledge to the individual, who transforms it into an implicit form.

For MNEs that operate across their intra-organizational network worldwide, the management of knowledge and creating channels that facilitate collaboration and exchange of ideas via global teams is critical. Global teams tend to have individuals selected from various geographic areas, serve different job functions, and attempt to work together on specific projects or address specific goals (Zander, Mockaitis, \& Butler, 2012). Different terms are used in the literature to describe global teams, including global virtual teams, geographically dispersed teams, multicultural distributed teams, cross-cultural distributed teams, and computer-mediated distributed teams (Connaughton \& Shuffler, 2007). While global teams provide access to a large pool of knowledge, there are many challenges associated with managing team members that can affect their performance. These challenges include issues related to cultural heterogeneity, including interpersonal relationships, communication between team members, and contextual factors such as the characteristics of team structure and the task of the team (Kotlarsky \& Oshri, 2005; Oshri, Van Fenema, \& Kotlarsky, 2008; Stahl, Maznevski, Voigt, \& Jonsen, 2010). In this study, we use globally distributed teams and cross-national teams interchangeably as they signify the same concept of the global team.

Firms can attempt to address these issues by ensuring consistency in processes and promoting an organizational culture that can minimize the effects of national culture differences. A strategy that MNEs often pursue in this regard is to use expatriates to manage their subsidiaries, and through that process, transfer the knowledge held by them (Fang, Jiang, Makino, \& Beamish, 2010). These expatriates take on a boundary-spanning role and contribute to the process of transferring tacit knowledge within the MNEs intra-organizational network (Spar, 1997). However, their global mobility is not always guaranteed, and MNEs need to consider alternatives to their expatriate option. For example, Guo et al. (2020) studied Indian management consulting MNE's operations and found out that some countries can restrict the movement of knowledge workers across national boundaries in non-technical industries. Accordingly, the firm responded by creating inpatriation programs that allow prospective 
employees from subsidiary locations to work in the Indian headquarters (HQs). This process allowed them to exchange organizational and technical knowledge, both explicit and tacit (Guo et al., 2020).

The restrictions on expatriate movement tend to be less common in technical industries such as in the IT sector. Therefore, we study this sector to understand how expatriates manage the subsidiaries of service MNEs from EMs and what processes are employed to facilitate the transfer and management of knowledge.

\section{Research Method}

This study adopts a qualitative, multi-case study approach to collect data for this study (Yin, 2014). The case study design is an appropriate choice for this study as it focuses on an underresearched phenomenon that requires further theoretical elaboration (Eisenhardt \& Graebner, 2007). The multi-case design allows for comparing several cases to understand their similar and differing features (Stake, 2013) and apply the theory to replicate findings or produce contradictory results (Welch, Piekkari, Plakoyiannaki, \& Paavilainen-Mäntymäki, 2011). This facilitates a comparative analysis of the cases that result in a much deeper understanding of the subject matter. New theoretical lenses or frameworks can be developed to extend existing theories and frameworks (Yin, 2014).

\section{Research Setting}

This study focuses on the operations of multiple Indian information technology (IT) firms' Australian operations to understand the processes employed by EMNEs to transfer, share and manage knowledge and teams worldwide. There are a few reasons that motivated the choice of Indian IT MNE's subsidiaries for this study. First, while there has been an increase in the number of studies covering EMNEs, the emphasis has been on manufacturing firms, and service MNEs have not received the same level of coverage (Rammal \& Rose, 2014). Service MNEs are inherently unique in developing tacit knowledge and transferring it across their global network. The few studies that have covered service MNEs in the EM setting find that the institutional environment in EMs influences the strategic response of these firms (Yuliansyah, Rammal, \& Rose, 2016), such as the MNE's choice of using expatriation or inpatriation as the preferred option to manage knowledge transfer (Guo et al., 2020). Finally, MNEs play a significant role in the Australian economy, as they do in many other countries (McDonnell, Stanton, \& Burgess, 2011). And, while Australia has been a long-term recipient of foreign direct investment (FDI), not much research has been conducted on MNEs in the Australian context (McDonnell et al., 2011). Indian MNEs in the IT sector have a strong presence in the Australian market. As many as 26 Indian IT firms have been reported to be operating in Australia with significant operations (Australia-India FTA Joint Report, 2010, p.62). Therefore, this article adds to this emerging and critical research area by studying the management of knowledge and global teams of Indian MNEs in Australia.

Second, the move towards the fourth industrial revolution (or Industry 4.0), including the growing emphasis on the Internet of things, and the digital economy's transformation, globally, increases the demand for IT-related services $(\mathrm{Li}, 2018)$. Indian firms are best placed to serve this demand as they have a global presence and can serve the needs of MNEs across their international subsidiary network. This is because Indian IT firms have a cost advantage and are five times cheaper than American firms, primarily due to the availability of lower labor costs (IBEF, 2020). Therefore, it is no surprise that Indian firms lead the global IT outsourcing 
industry, with nearly 55 percent of the market share (IBEF, 2018). Finally, the Indian government's support for the IT sector plays a critical role in its success. Under the 'Start-up India' program, IT firms can receive tax exemptions of up to three years, and they are also facilitated in areas of capital sourcing.

The last two decades have seen an increased emphasis on technology and digital transformation. The bricks-and-mortar business presence model is being replaced with digital presence and digital payment options that allow businesses to operate 24/7 and offer their products beyond their domestic market (Mishra \& Mahanty, 2015). The rapid pace at which this growth is occurring has left many firms unable to develop these technological skills within their organization organically, and they outsource these activities to specialist IT firms. As discussed, India is a leader in this field, with foreign firms offshoring their activities to Indian IT firms that boast a vital infrastructure (Mishra \& Mahanty, 2014). However, concerns about data retention, understanding customer needs, and local requirements mean that many large Indian IT MNEs have an onshore presence in foreign countries. Within this model, customers, who are typically other firms, send their work offshore to India, where part of the work gets done. In addition, some members from the project teams are sent onsite to the customer location (i.e., where the firm is based) to work with the customer where they define project requirements, coordinate with the offshore team, and attempt to secure more business from the customer (Shah, Russell, \& Wilkinson, 2017). This onsite-offshore relationship requires efficient systems and the right people to manage the operations, transfer knowledge, and act as a bridge between the headquarters and the subsidiary (Kotlarsky, Scarbrough, \& Oshri, 2014; Vlaar, van Fenema, \& Tiwari, 2008). Although IT firms can have different business models, such as the capability maturity model (Salman et al., 2018), the onsite-offshore business model is the dominant model of IT service used by Indian IT firms (Lee, Park, \& Krishnan, 2014). Given how integral this model is to the operations and success of Indian IT MNEs, we examine this hybrid model in a globally distributed or cross-national team context to understand how the model facilitates knowledge transfer in Indian IT firms. The various stages of knowledge transfer highlighted in the SECI model helped us analyze the strategies employed by Indian MNEs and the processes they follow to manage the knowledge within the intra-organizational network.

\section{Data collection and analysis}

We study Indian MNEs that operate in the IT-enabled/business process outsourcing (ITes/BPO) and IT software and service (ITSS) sectors to explore and investigate these issues. As the emphasis is on knowledge management and service firms, Indian IT hardware manufacturing firms are excluded from this sample. We identified the case firms from the national association of software and services companies (NASSCOM) registered directory of member firms and organizations that operate in the domestic and international markets. We initially identified 20 Indian IT case firms and contacted them, but only 16 firms agreed to participate in the study. The case respondents in the Australian subsidiaries were selected using a mix of convenience and purposive sampling approaches and contacted through telephone calls and emails with contacts in the Consulate General of India Sydney, the Australia-India Business Council, and the Indo-Australia Chamber of Commerce. The case sample criteria that we developed for this study included selecting Indian IT firms that have HQs in India and have operated in Australia for a minimum of one year, including having a physical subsidiary in Australia either through Greenfield investment or a merger and acquisition (M\&A). We purposefully ignored those firms that entered Australia through a joint venture (IJV) arrangement. The case firms were sent an information pack that informed them about the study, 
their participation, and the privacy and confidentiality procedures. Written approval and consent were obtained from all the firms and their representatives.

Face-to-face interviews were conducted with 20 senior directors and managers based in subsidiaries across the Australian states of New South Wales, Victoria, Queensland, South Australia, and Western Australia. We used the semi-structured interview style, which allows the researcher to seek details and clarify the case firm's processes. In qualitative studies, interviews often seek to penetrate the social life beyond appearances and manifest meanings as this requires the researcher to be immersed in the field of inquiry to establish a fruitful relationship with the respondents and through theoretical contemplation to address the research problem in depth (Crouch \& McKenzie, 2006). As a result, a small number of cases (20 or less) are considered sufficient to facilitate the researcher's close association with the respondents and to enhance the validity of fine-grained, in-depth inquiry in its naturalistic setting, which indicates that the issue of sample size has little bearing on the project's basic logic (Crouch \& McKenzie, 2006). Therefore, despite the limited number of case firms and respondents, sufficient data was collected by the researchers to attain saturation. Each interview lasted between 60 to 80 minutes. The respondents managed the local operations of their respective subsidiaries in Australia. Their role includes managing all aspects of subsidiary operations, from sales and marketing to human resource and human capital, and operations management. The interview questions were developed from the literature on onsite-offshore concept and the SECI model. Some of the example questions asked to the subsidiary directors and managers include: What is the total proportion of Indian expatriate managers instead of Australian managers employed in your subsidiary? How often do managers from Indian HQs visit the subsidiary, and what is the purpose of their visit? In what capacity does the Indian HQ intervene in the decisions of the subsidiary? Does the subsidiary maintain contact with other subsidiaries within your MNE network for knowledge sharing? The Indian IT case firms' and respondents' information is provided in Table 1.

\section{Insert Table I here $* * * * *$}

The interviews focused on the knowledge management and transfer process between the Indian HQs and the Australian subsidiary and the role and management of expatriates. The interviews were conducted in English and were recorded using a digital voice recorder. In addition, contextual information about the company and the Indian and Australian IT sectors was collected from secondary sources such as websites, company reports, news, and magazine articles.

We transcribed the interviews and aligned the secondary data with the primary data to gain an overall sense of the collected information. The data was then carefully studied, leading to developing key categories and coding the organized information under themes (Hartley, 2004). Each member of the author team followed the process individually to ensure that the final themes were developed following a replicable, consistent, and valid process. We also examined the data to test whether it fits or failed the expected categories and how it did or did not relate to the identified themes (Hartley, 2004). Once the data coding reached the saturation point, the pattern matching technique was used to analyze it (Voss, Tsikriktsis, \& Frohlich, 2002). This involves a detailed case study write-up for each case organization that identifies patterns from each case to emerge, which is then used to make generalizations (Eisenhardt \& Graebner, 2007). Finally, meaningful observations were created from the comparative analyses of all the 
cases to position the existing theory and literature findings to draw conclusions (Miles \& Huberman, 1994). These themes form the basis of our findings that are presented next.

\section{Findings}

Two key themes emerged from our analysis of the data. They cover the use of expatriates and the overarching role of the onsite-offshore business model in the one-way knowledge transfer process between the Indian HQs and the Australian subsidiaries and the limited role of the subsidiaries and host country nationals (HCNs) in the knowledge transfer process.

\section{The use of expatriates and onsite-offshore business model for knowledge transfer}

We sought responses from the respondents about how the Indian IT firms control the teams remotely and what processes are in place to exchange ideas, information, and access to knowledge. Indian IT firms use two essential practices

First, Indian IT firms use expatriation as one of the key practices to transfer home country knowledge and deliver IT service to their customers in Australia and manage the subsidiaries. In fact, at the top and middle-level management (i.e., managerial and technical staff), most of the employees working in the Australian subsidiaries are Indian nationals who are sent from the parent country operations in India and occasionally from the third country operations within the intra-organizational network. These expatriates are highly skilled experts in various IT domains. They come to Australia to work on and manage specific IT tasks and projects determined based on customer demands. In doing so, these expatriates carry with them the home country knowledge required by Indian IT firms to deliver their service in Australia. For example, this not only includes explicit knowledge of organizational 'best' practices and policies that are documented and followed within the HQ and the global MNE network, but it also includes tacit knowledge of specific IT know-how and the corporate culture that is internalized by organizational members working in Indian IT firms. The following three quotes by key respondents highlight the importance of sending expatriates by Indian IT firms:

It is mainly the skills and the expertise that we bring people over as we don't always have these skills available in the Australian labor market, so we have to get them from India as these kinds of specialists are hard to find locally - Firm 2 Respondent

The way we work is we have a global pool of resources, and a lot of our employees move around different regions, so we don't just have employees who come from our Indian operations but also our operations in the US, UK, or Europe for projects, and it happens very often - Firm 6 Respondent.

These are broader guidelines that already exist at our corporate. We then transmit them into our country-specific operations, and we make sure that our employees follow them because if we don't, our head office would be concerned about the way things are being done-Firm 11 Respondent.

Through the widespread deployment of expatriates, Indian IT firms, besides delivering service to their customers, also exert a high degree of centralization and standardization across the subsidiaries to bring uniformity in their global operations. Second, Indian IT firms combine this practice with their onsite-offshore business model to deliver IT service at cost-efficient prices whilst driving a high-value proposition which allows Indian IT firms to compete with 
other smaller and medium-sized firms operating in the local host country market. The interviews quotes by respondents of firms 12 and 14 explain how Indian IT firms use this model for their operational and business strategy purposes:

We follow the onsite-offshore business model where we have a team of specialist employees that works in India and does the execution of our IT services but onsite, we have a separate team that looks after its local management right from determining its initial requirements to its installation and its maintenance - Firm 12 Respondent.

Our employees have a lot of experience in the business model we use and how our IT projects are executed and delivered, which, unfortunately, the local employees do not understand - Firm 14 Respondent.

In terms of our findings, this business model is significant because it provides industry-specific insights that explain the knowledge transfer and sharing process by Indian IT MNEs. As the data has shown, the Australian subsidiaries of Indian IT firms rely on the knowledge carried by expatriates from the parent company operations to drive the delivery of IT service using the onsite-offshore business model. This model leverages the knowledge created in the parent country operations and transferred and used by the local subsidiaries. As a result, this model has enhanced how knowledge is transferred and readily available across the subsidiaries as they are entirely dependent on their parent country operations to provide and share knowledge. This sentiment is conveyed by one of the respondents.

Whatever our larger company does, we perform the same set of activates in our local affiliate - Firm 8 Respondent.

Indian IT firms provide service to their Australian customers across various IT domains and verticals using the onsite-offshore business model. This model allows Indian IT firms to use expatriates to transfer home country knowledge to their foreign operations. Not only does this model provides Indian IT firms with the competitive advantage they need to survive in the host country market, but it also ensures that there is close integration between the HQ and the subsidiary in transferring and using the knowledge created in the home country operations.

\section{The role of HCNs and subsidiaries in knowledge transfer}

The expatriation practices adopted by Indian IT firms in Australia explain how these employees fulfill a boundary-spanning role of knowledge workers as they work in global teams. Despite the technological focus and nature of the industry, the firms tend to use global teams that are physically present onsite in the host country and offshore in the home country. The HCNs were employed at the functional and administrative levels. Their knowledge of the local market, regulations, and consumer needs were necessary for Indian IT firms to reduce their liability of foreignness. As one of the key informants explained:

When we are pursuing a deal, the pitch team would comprise people from Australia, the sales, they go to the marketing people that are based in Australia. The domain experts could be in Australia, or they could be in India, or they could be in some other part of the world. And then, you know, you would have the solutions team again, you know, based in any part of the world, largely because we have a majority of employees in India, then the sort of the ratio gets tilted towards India. So, whenever we are pursuing a deal, 
the entire team comes together it comprises a cross-functional team in India or Australia, and they sit down as a team. - Respondent Firm 14

However, a deeper investigation of the Australian operations highlighted a lack of interaction between the two groups - i.e., the expatriates who assumed managerial and technical roles in the subsidiary and the HCNs who assumed functional or administrative roles. While the local staff was deemed necessary for the day-to-day operations, they were not involved in any decision-making. Hence, the knowledge exchange between the expatriates and seemed to be minimal, which indicated a flawed knowledge management process. Furthermore, the subsidiaries in Australia did not create new knowledge and send it back to the parent company operations. Therefore, they depended on the head office to transfer knowledge and other resources (i.e., capital, technology, human resources). The two important reasons for this were the significant presence of expatriates as parent country nationals (PCNs) and the onsiteoffshore business model, which creates a system where work is jointly shared between the home and host country operations and which has allowed the subsidiaries to be tightly integrated with their parent companies thus limiting its strategic role in the knowledge management process. One respondent explained that the expertise lies at the HQs, which the customers want to access. In contrast, the other respondent highlighted the cost-effectiveness of bringing people from India:

Our specialists come from India because they have a certain skill set, and this is where our center of excellence is located, and that is what our customers demand, so the decisions are made in India [while] taking the Australian customers into account. Respondent Firm 8

We bring expatriates because these decisions are driven by costs, and the aim is to simplify our business, so that means less overhead, less administration, and that is why the decision-making rests in the hands of the corporate - Respondent Firm 3.

Another respondent emphasized the importance of close coordination between the subsidiary and the HQ and how expatriates and the onsite-offshore business model act as a bridge between the two business units in knowledge creation and transfer.

The majority of our subsidiary staff are people who come from our parent company, and while this may change in the future, I have to ensure that our employees remain well integrated with the larger company - Respondent Firm 13.

We are a matrix organization, so we work very closely with our Indian counterpart as this is where we get our resources from, and that is where our global strategy is formulated - Respondent Firm 9.

Interestingly, while the majority of the case firms in our sample suggest that Indian IT firms transfer home country knowledge to their Australian subsidiaries, there were a couple of case firms where the subsidiaries reported an active role in knowledge creation and dissemination back to the Indian operations which lead to a two-way knowledge transfer. The reason for this came down to the knowledge management approach taken by these firms, as they saw the importance of incorporating the knowledge and skills available in Australia. 
A lot of our consultants in Australia work with our European subsidiaries and our subsidiaries in the U.S., and we make sure that we have knowledge-sharing sessions through teleconferencing - Respondent Firm 6

This reflects that while some Australian subsidiaries may have played a role in local knowledge creation and its reverse diffusion back to the parent company operations, the knowledgecreating and sharing at the host country level was still minimal as the use of the onsite-offshore business model and PCN expatriates ensured that knowledge was being transferred in the form of a forward diffusion across the subsidiaries. This may be a very industry-centric outcome, but based on this sample, there is no question that Indian IT firms are transferring home country knowledge to Australia than vice versa.

\section{Discussion and conclusion}

The findings of this study highlight important theoretical and practical issues in managing dispersed global operations, cross-national teams, and knowledge transfer. There is a lack of research on the evolving nature of global teams in MNEs (Connaughton \& Shuffler, 2007; Gibson, Dunlop, \& Cordery, 2019) and their role in collaborating and participating in business operations across national borders has not been well understood. Furthermore, within globally distributed work, knowledge transfer has become a vital issue as the success of an organization is often dependent upon the rapid transfer of business and technological knowledge from and too offshore facilities (Bosch-Sijtsema, Ruohomaki, \& Vartiainen, 2009; Bosch-Sijtsema, Fruchter, Vartiainen, \& Ruohomaki, 2011; Joshi, Sarker. \& Sarker, 2007; Oshri et al., 2008). In this context, not much research has looked at knowledge transfer between dispersed and globally distributed teams in EMNEs, including understanding the knowledge-sharing processes in global teams.

The data analysis shows that the onsite-offshore business model is integral to Indian IT MNE's ability to manage globally dispersed, cross-national teams. This business model enables the team members working on IT projects to be located between the home country (offshore) and the host country (onsite) to coordinate these projects. And, it allows them to draw on their firmspecific capabilities (i.e., human capital, technology, know-how, etc.) to transfer knowledge between the HQs and the subsidiaries. The majority of these onsite team members are highly experienced and skilled expatriates who draw on the centralized expertise to carry out their onsite duties. This provides Indian IT MNEs with a significant cost advantage. Still, it also enables them to compete with other players in the market to offer IT services that are costeffective and tailored to the needs of their customers and maintain an international competitive advantage. Therefore, reflecting on the onsite-offshore phenomenon, we find that the customers in developed countries are often attracted to Indian IT firms due to their expertise at home, their global portfolio, and their cost-efficiencies. To maintain these advantages, much of the work is undertaken by experts in the home country. The physical presence of specialized expatriates who draw on the onsite-offshore relationship in host countries assures local responsiveness and data storage within the host country and under the local regulations. This results in a one-way transfer or forward diffusion of knowledge. The subsidiaries entirely depend on their HQs for all types of support, including sharing home country knowledge and other resources. As a result, the use of expatriates to manage the Australian subsidiaries of Indian IT MNEs using the onsite-offshore business model seems consistent with the idea of sharing explicit and tacit knowledge via socialization, externalization, and internalization as espoused by Nonaka and Takeuchi (1995). 
Indian IT MNEs use skilled expatriates who engage in the socialization process to pass on tacit knowledge through practice, guidance imitation, and observation. This is done by primarily communicating the HQs 'way of doing things' to the subsidiaries and building a culture that results in a shared corporate culture and strategic objectives through the transfer of expatriates using the onsite-offshore model. The externalization phase involves leveraging on the centralized expertise where 'best' practices and organizational know-how are kept into documents and manuals and can be easily assessed by the subsidiaries using their organization's intranet portal. Finally, the presence of expatriates in the subsidiaries also results in the internalization of the explicit knowledge into tacit knowledge through coordination with the offshore team based in the home-country operations. No combination of integrating knowledge sources to create new knowledge was found. Therefore, we deduce that EMNEs that operate in the service industry and use cross-national teams to transfer and share knowledge use the socialization, externalization, and internalization mechanisms. However, Indian expatriates do not transfer best practices to host-country nationals that would allow them to combine new knowledge with their existing background. We believe our study contributes by applying this theory to understand better knowledge transfer mechanisms and processes in globally distributed teams that use the onsite-offshore business model (Mattarelli \& Gupta, 2009) in EMNEs from the service industry.

In terms of the limited role of HCNs and subsidiaries in creating new knowledge, we find that the HCNs do not have the opportunities to engage directly with the headquarters leadership team. While the role of subsidiaries of Indian EMNEs in the service industry is purely functional where the digital nature of the main activities, including software development undertaken by the Indian IT firms acting as vendors, is conducted in India with support from expatriates in Australia working as knowledge workers. For example, Tata Consultancy Services (TCS) has locked into a strategic partnership with the Australian energy giant AGL Energy where TCS used its "cloud migration factory" to transition 50 percent of AGL's corporate workload to the cloud whilst providing support to AGL's data centers based in its Melbourne and Sydney offices (Talevski, 2020). As such, Australian firms benefit significantly from the services of Indian IT firms as they receive high-quality IT service and support that are tailored to their unique specifications and needs and that are cost-effective, both for the service provider and the service recipient. When analyzed through the SECI framework, it is reasonable to assume that Australian firms may also be able to use the services received from the Indian IT firms to create and share their knowledge through either of the four components. However, any conclusive assumptions in this regard are beyond the scope of this study. For the Indian IT MNEs, while this does represent an opportunity to keep the costs down and maintain a healthy profit, the strategy is not without limitations. The failure to learn from the local employees or transfer knowledge to them exposes them to many risks. For example, as pointed out by DeNisi and Sonesh (2016), the relationship between the expatriate HCNs is essential for the successful outcome of the international assignment. Furthermore, lack of investment in local knowledge creation using their experiences from operating in developed countries exposes the firms to disruptions which many firms are experiencing with the COVID-19 pandemic that began in 2020. Worldwide, many expatriates had to return to their HQs during the pandemic (Haak-Saheem, 2020), which exposed firms that did not have a solid local knowledge base.

Australia is a small open economy, and many countries share these economic and demographic features in Western Europe (Falahat, Lee, Ramayah, \& Soto-Acosta, 2020). By limiting the engagement with the local operations, lack of investment in research and development ( $\mathrm{R} \&$ $\mathrm{R} \& \mathrm{D}$ ), and generating local knowledge, Indian IT firms miss out on the opportunity to learn 
new practices that could be useful in other country contexts. MNEs use this reverse knowledge transfer and a two-way approach to become more innovative and improve their competitiveness which helps them overcome the various liabilities associated with internationalization (Mudambi, Piscitello, \& Rabbiosi, 2014; Rabbiosi \& Santangelo, 2013). And, superior knowledge management capabilities ultimately help MNEs improve their performance (Dabic \& Kiessling, 2019). For instance, studies by Peng, Qin, Chen, Cannice and Yang (2017) and Zhang and Edwards (2007) on subsidiaries of Chinese MNEs in the United States has shown that reverse knowledge transfer not only leads to the diffusion of best practices but also allowed the HQ to enhance its strategic asset seeking motivations. Therefore, parent HQs and MNEs benefit significantly from the reverse knowledge transfer (Nair, Demirbag, Mellahi, \& Pillai, 2018). For the subsidiaries, gaining local knowledge is vital in understanding the host country's market conditions and assisting the HQ in building knowledge management capabilities (Griffith, Kiessling, \& Dabic, 2012). Indeed, the motivation of the MNE should be seen as a critical factor in the need for knowledge transfer between the HQ and the subsidiary or vice versa (Song, 2014). For example, the geographical distance between the HQ and the subsidiary can influence MNE's ability to transfer knowledge (Vlajcic et al., 2019). However, the findings from this study raise questions about claims made that only MNEs from developed countries limit the knowledge flow from the host country and emphasize uni-directional flow from the HQ (Michailova \& Mustaffa, 2012). We find that EMNEs also display a similar behavior and limit the amount of knowledge flow from the HQ to the subsidiary.

Lastly, in light of the SECI model, we find that aspects of this model are limited to expatriates in managerial and technical positions at the subsidiary who interact with their HQs. While using expatriates may allow MNEs to speed up their internationalization owing to the knowledge possessed by them (Dabic, Gonzalez-Loureiro, \& Harvey, 2015), in our sample, the expatriate's interaction is not translated into an externalized and explicit form of knowledge that could be shared with others in the subsidiary (i.e., the HCNs). Thus, the knowledge generated remains centralized at the HQs rather than transferred through the MNE's interorganizational network. As such, the knowledge flow that one expects through the onsiteoffshoring arrangement is lacking in the operations of the Indian MNEs. Taking a long-term perspective, this lack of new knowledge generation could threaten the long-term profitability of Indian MNEs as new competitors from China (Jia, Kenney, \& Zysman, 2018) and other EMs continue to expand their global operations and offer products and services at a more competitive rate. Figure 1 illustrates the relationship between the Indian HQ and the Australian subsidiary, and the knowledge transfer process undertaken by the expatriates.

*****

Insert Figure I here

$* * * * *$

To conclude, this study makes a significant contribution by exploring how EMNEs manage knowledge and their team members in their international subsidiaries and the role of expatriates in their global operations. Like all studies, this research also has some limitations that may guide future research. There is only one host country that was covered in this study. Future studies could extend this research to test whether the behavior of service MNEs is different in countries with a larger population and local competition with large firms. Replicating this study in other service sectors (including those considered non-technical) could also add to this emerging stream of literature. This study has offered unique insights into globally distributed cross-national teams and work arrangements using the distinct onsite-offshore business model used by Indian MNEs from the IT service industry. 


\section{References}

Australia-India Joint Free Trade Agreement Report (2010), Australia-India joint free trade agreement (FTA) feasibility study, Australian Government Department of Foreign Affairs and Trade. ISBN: 978-1-921612-32-9. https://www.dfat.gov.au/sites/default/files/Australia-India-Joint-FTA-FeasibilityStudy.pdf

Baumard, P. (1999), Tacit Knowledge in Organizations, SAGE, London.

Bosch-Sijtsema, P. M., Ruohomaki, V. and Vartiainen, M. (2009), "Knowledge work productivity in distributed teams", Journal of Knowledge Management, Vol. 13 No. 6, pp. 533-546.

Bosch-Sijtsema, P. M., Fruchter, R., Vartiainen, M. and Ruohomaki, V. (2011), "A framework to analyze knowledge work in distributed teams", Group \& Organization Management, Vol. 36 No. 3, pp. 275-307.

Brymer, R. A., Boss, D. S., Uhlenbruck, K. and Bierman, L. (2020), "Internationalization's Effect on Mobility and Firms' Employee-Based Resources", Academy of Management Perspectives, Vol. 34 No. 1, pp. 114-134.

Connaughton, S. L. and Shuffler, M. (2007), "Multinational and Multicultural Distributed Teams: A Review and Future Agenda", Small Group Research, Vol. 38 No. 3, pp. 387-412.

Crouch, M. and McKenzie, H. (2006), "The logic of small samples in interview-based qualitative research", Social Science Information, Vol. 45 No. 4, pp. 483-499.

Dabic, M., Gonzalez-Loureiro, M. and Harvey, M. (2015), "Evolving research on expatriates: What is 'known' after four decades (1970-2012)", International Journal of Human Resource Management, Vol. 26 No. 3, pp. 316-337.

Dabic, M. and Kiessling, T. (2019), "The performance implications of knowledge management and strategic alignment of MNC subsidiaries", Journal of Knowledge Management, Vol. 23 No. 8, pp. 1477-1501.

DeNisi, A. S. and Sonesh, S. (2016), "Success and failure in international assignments", Journal of Global Mobility, Vol. 4 No. 4, pp. 386-407.

Earley, P. C. and Gibson, C. B. (2002), Multinational Work Teams: A New Perspective. Lawrence Erlbaum Associates, Inc., Mahwah, NJ.

Eisenhardt, K. M. and Graebner, M. E. (2007), "Theory-building from cases: opportunities and challenges", Academy of Management Journal, Vol. 50 No. 1, pp. 21-32.

Falahat, M., Lee, Y. Y., Ramayah, T. and Soto-Acosta, P. (2020), "Modelling the effects of institutional support and international knowledge on competitive capabilities and international performance: Evidence from an emerging economy", Journal of International Management, Vol. 26 No. 4, pp. 100779.

Fang, Y., Jiang, G. L. F., Makino, S. and Beamish, P. W. (2010), "Multinational firm knowledge, use of expatriates, and foreign subsidiary performance", Journal of Management Studies, Vol. 47 No. 1, pp. 27-54.

Gibson, C. B., Dunlop, P. D. and Cordery, J. L. (2019), "Managing formalization to increase global team effectiveness and meaningfulness of work in multinational organizations", Journal of International Business Studies, Vol. 50 No. 6, pp. 10211052.

Goodall, K. and Roberts, J. (2003), "Repairing Managerial Knowledge-Ability Over Distance", Organization Studies, Vol. 24 No. 7, pp. 1153-1175. 
Griffith, D. A., Kiessling, T. and Dabic, M. (2012), "Aligning strategic orientation with local market conditions: Implications for subsidiary knowledge management", International Marketing Review, Vol. 29 No. 4, pp. 379-402.

Guo, Y., Jasovska, P., Rammal, H. G. and Rose, E. L. (2020), "Global mobility of professionals and the transfer of tacit knowledge in multinational service firms", Journal of Knowledge Management, Vol. 24 No. 3, pp. 553-567.

Haak-Saheem, W. (2020), "Talent management in Covid-19 crisis: how Dubai manages and sustains its global talent pool", Asian Business \& Management, Vol. 19, pp. 298-301.

Hartley, J. (2004), "Case study research", in Cassell, C. and Symon, G. (Eds.), Essential guide to qualitative methods in organizational research. Sage, London, pp. 323-333.

Harzing, A. W., Pudelko, M. and Sebastian Reiche, B. (2016), "The bridging role of expatriates and inpatriates in knowledge transfer in multinational corporations", Human Resource Management, Vol. 55 No. 4, pp. 679-695.

Hinds, P., Liu, L. and Lyon, J. (2011), "Putting the Global in Global Work: An Intercultural Lens on the Practice of Cross-National Collaboration", Academy of Management Annals, Vol. 5 No. 1, pp. 135-188.

IBEF. (2018), "IT \& ITes. IBEF Report", available at: https://www.ibef.org/download/ITITeS-Report-July-2018.pdf (accessed 25 September 2020).

IBEF. (2020), "Indian IT \& ITES report", available at: https://www.ibef.org/industry/information-technology-india.aspx (accessed 5 September 2020).

Jia, K., Kenney, M. and Zysman, J. (2018), "Global Competitors? Mapping the Internationalization Strategies of Chinese Digital Platform Firms", in Rob van, T., Alain, V. and Lucia, P. (Eds.), International Business in the Information and Digital Age. Emerald Publishing Limited, pp. 187-215.

Joshi, K. D., Sarker, S. and Sarker, S. (2007), "Knowledge transfer within information systems development teams: Examining the role of knowledge source attributes", Decision Support System, Vol. 43 No. 2, pp. 322-335.

Kong, L., Ciabuschi, F. and Martín, O. M. (2018), "Expatriate managers' relationships and reverse knowledge transfer within emerging market MNCs: The mediating role of subsidiary willingness", Journal of Business Research, Vol. 93, pp. 216-229.

Kotlarsky, J. and Oshri, I. (2005), "Social ties, knowledge sharing and successful collaboration in globally distributed system development projects", European Journal of Information Systems, Vol. 14 No. 1, pp. 37-48.

Kotlarsky, J., Scarbrough, H. and Oshri, I. (2014), "Coordinating expertise across knowledge boundaries in offshore-outsourcing projects: The role of codification", MIS Quarterly, Vol. 38 No. 2, pp. 607-628.

Lagerström, K. and Andersson, M. (2003), "Creating and sharing knowledge within a transnational team--the development of a global business system", Journal of World Business, Vol. 38 No. 2, pp. 84-95.

Lee, K., Park, T. Y. and Krishnan, R. T. (2014), "Catching-up or leapfrogging in the Indian IT service sector: Windows of opportunity, path-creating, and moving up the value chain", Development Policy Review, Vol. 32 No. 4, pp. 495-518.

Li, L. (2018), "China's manufacturing locus in 2025: With a comparison of "Made-in-China 2025" and "Industry 4.0"", Technological Forecasting \& Social Change, Vol. 135 No. October, pp. 66-74.

Mattarelli, E., and Gupta, A. (2009), "Offshore-onsite subgroup dynamics in globally distributed teams" Information Technology \& People, Vol. 22 No. 3, pp. 242-269. 
McDonnell, A., Stanton, P. and Burgess, J. (2011), "Multinational enterprises in Australia: Two decades of international human resource management research reviewed", Asia Pacific Journal of Human Resources, Vol. 49 No. 1, pp. 9.35.

McDonnell, A., Russell, H., Sablok, G., Stanton, P., Burgess, J. and Bartram, T. (2011), "Methodology and research on the human resource practices of multinational enterprises in Australia", Australian Bulletin of Labour, Vol. 37 No. 2, pp. 230-245.

Mehreen, H., Rammal, H.G., Pereira, V. and Del Giudice, M. (2021), "Investigating the influence of absorptive capacity of recipients within cross-border transfer of knowledge: evidence from emerging markets", International Marketing Review, Vol. Earlycite: 10.1108/IMR-11-2020-0264.

Michailova, S., and Mustaffa, Z. (2012), "Subsidiary knowledge flows in multinational corporations: Research accomplishments. gaps, and opportunities", Journal of World Business, Vol. 47 No. 3, pp. 383-396.

Miles, M. B. and Huberman, A. M. (1994), Qualitative data analysis: an expanded sourcebook, Sage Publications, Thousand Oaks, CA.

Minbaeva, D. B. and Michailova, S. (2004), "Knowledge transfer and expatriation in multinational corporations", Employee Relations, Vol. 26 No. 6, pp. 663-679.

Mishra, D. and Mahanty, B. (2014), "The effect of onsite-offshore work division on project cost, schedule, and quality for re-engineering projects in Indian outsourcing software industry", Strategic Outsourcing: An International Journal, Vol. 7 No. 3, pp. 198225.

Mishra, D. and Mahanty, B. (2015), "Business knowledge requirements and onsite offshore work division in Indian software outsourcing projects", Strategic Outsourcing: An International Journal, Vol. 8 No. 1, pp. 76-101.

Mudambi, R. and Navarra, P. (2004), "Is Knowledge Power? Knowledge Flows, Subsidiary Power and Rent-Seeking within MNCs", Journal of International Business Studies, Vol. 35 No. 5, pp. 385-406.

Mudambi, R., Piscitello, L. and Rabbiosi, L. (2014), "Reverse knowledge transfer in MNEs: Subsidiary innovativeness and entry modes", Long Range Planning, Vol. 47 No. 1-2, pp. 49-63.

Nonaka, I. and Takeuchi, H. (1995), The knowledge creating company: How Japanese companies create the dynamics of innovation, Oxford University Press, New York.

O’Higgins, C., Andreeva, T. and Aramburu Goya, N. (2021), "International management challenges of professional service firms: a synthesis of the literature", Review of International Business and Strategy, Vol. ahead-of-print. https://doi.org/10.1108/RIBS-07-2020-0087

Oshri, I., Van Fenema, P. and Kotlarsky, J. (2008), "Knowledge transfer in globally distributed teams: The role of transactive memory", Information Systems Journal, Vol. 18 No. 6, pp. 593-616.

Peng, Z., Qin, C., Chen, R. R., Cannice, M. V. and Yang, X. (2017), "Towards a framework of reverse knowledge transfer by emerging economy multinationals: Evidence from Chinese MNE subsidiaries in the United States", Thunderbird International Business Review, Vol. 59 No. 3, pp. 349-366.

Rabbiosi, L. and Santangelo, G. D. (2013), "Parent company benefits from reverse knowledge transfer: The role of the liability of newness in MNEs", Journal of World Business, Vol. 48 No. 1 , pp. $160-170$.

Rammal, H. G. and Rose, E. L. (2014), "New Perspectives on the Internationalization of Service Firms", International Marketing Review, Vol. 31 No. 6, pp. 550-556.

Riusala, K. and Suutari, V. (2004), "International knowledge transfers through expatriates", Thunderbird International Business Review, Vol. 46 No. 6, pp. 743-770. 
Salman, R., Daim, T., Raffo, D. and Dabic, M. (2018), "Exploring capability maturity models and relevant practices as solutions addressing information technology service offshoring project issues", International Journal of Management Science and Engineering Management, Vol. 13 No. 3, pp. 147-157.

Schweiger, D. M., Atamer, T. and Calori, R. (2003), "Transnational project teams and networks: making the multinational organization more effective", Journal of World Business, Vol. 38 No. 2, pp. 127-140.

Shah, D., Russell, B. and Wilkinson, A. (2017), "Opportunity and opportunism: The expatriation practices of Indian information technology multinational corporations", Journal of International Management, Vol. 23 No. 2, pp. 139-150.

Song, J. (2014), "Subsidiary absorptive capacity and knowledge transfer within multinational corporations", Journal of International Business Studies, Vol. 45 No. 1, pp. 73-84.

Spar, D. L. (1997), "Lawyers Abroad: The Internationalization of Legal Practice", California Management Review, Vol. 39 No. 3, pp. 8-28.

Stahl, G. K., Maznevski, M. L., Voigt, A. and Jonsen, K. (2010), "Unraveling the effects of cultural diversity in teams: A meta-analysis of research on multicultural work groups", Journal of international business studies, Vol. 41 No. 4, pp. 690-709.

Stake, R. E. (2013), Multiple Case Study Analysis, Guilford Press, New York, NY.

Talevsky, J. (2020), Tata consultancy services locks in AGL cloud transformation initiative, ARN, November 4, 2020. https://www.arnnet.com.au/article/684247/tata-consultancyservices-locks-agl-cloud-transformation-initiative.

Vlaar, P. W. L., van Fenema, P. C. and Tiwari, V. (2008), "Cocreating understanding and value in distributed work: How members of onsite and offshore vendor teams give, make, demand and break sense", MIS Quarterly, Vol. 32 No. 2, pp. 227-255.

Vlajcic, D., Marzi, G., Caputo, A. and Dabic, M. (2019), "The role of geographical distance on the relationship between cultural intelligence and knowledge transfer", Business Process Management Journal, Vol. 25 No. 1, pp. 104-125.

Voss, C., Tsikriktsis, N. and Frohlich, M. (2002), "Case research in operations management", International Journal of Operations \& Production Management, Vol. 22 No. 2, pp. 195-219.

Welch, C., Piekkari, R., Plakoyiannaki, E. and Paavilainen-Mäntymäki, E. (2011), "Theorising from Case Studies: Towards a Pluralist Future for International Business Research", Journal of International Business Studies, Vol. 42, pp. 740-762.

Yin, R. K. (2014), Case study research: Design and methods. Sage publications.

Yuliansyah, Y., Rammal, H. G. and Rose, E. L. (2016), "Business Strategy \& Performance in Indonesia’s Service Sector", Journal of Asia Business Studies, Vol. 10 No. 2, pp. 164182.

Zander, L., Mockaitis, A. I. and Butler, C. L. (2012), "Leading global teams", Journal of World Business, Vol. 47 No. 4, pp. 592-603.

Zhang, M. and Edwards, C. (2007), "Diffusing 'best practice' in Chinese multinationals: The motivation, facilitation and limitations", International Journal of Human Resource Management, Vol. 18 No. 12, pp. 2147-2165. 
Table I. Indian IT case firms and respondents' profile

\begin{tabular}{|c|c|c|c|c|c|c|c|}
\hline $\begin{array}{l}\text { Indian IT } \\
\text { case firms }\end{array}$ & $\begin{array}{c}\text { Location of } \\
\text { Corporate HQ in } \\
\text { India (by State) }\end{array}$ & $\begin{array}{c}\text { Location of the } \\
\text { subsidiary in } \\
\text { Australia (by State) }\end{array}$ & $\begin{array}{c}\text { Number of } \\
\text { respondents in } \\
\text { each case firm }\end{array}$ & $\begin{array}{l}\text { Origin of } \\
\text { respondents } \\
\text { within the } \\
\text { MNE intra- } \\
\text { organizational } \\
\text { network }\end{array}$ & $\begin{array}{c}\text { Respondent's role within the } \\
\text { subsidiary }\end{array}$ & $\begin{array}{c}\text { Composition of } \\
\text { globally distributed } \\
\text { teams }\end{array}$ & $\begin{array}{c}\text { Knowledge } \\
\text { transfer/exchange } \\
\text { between HQ and } \\
\text { subsidiary }\end{array}$ \\
\hline Firm 1 & Telangana & Queensland & 2 & $\begin{array}{l}\text { Parent country, } \\
\text { Host country }\end{array}$ & $\begin{array}{l}\text { Senior director } \\
\text { Senior manager }\end{array}$ & Onsite-offshore & One-way \\
\hline Firm 2 & $\begin{array}{c}\text { Haryana and } \\
\text { Karnataka }\end{array}$ & New South Wales & 1 & Parent country & Senior director & Onsite-offshore & One-way \\
\hline Firm 3 & Maharashtra & New South Wales & 1 & Parent country & Senior director & Onsite-offshore & One-way \\
\hline Firm 4 & Karnataka & New South Wales & 1 & Host country & Senior director & Onsite-offshore & One-way \\
\hline Firm 5 & Telangana & Victoria & 1 & Parent country & Senior director & Onsite-offshore & One-way \\
\hline Firm 6 & Karnataka & New South Wales & 1 & Parent country & Senior director & Onsite-offshore & Two-way \\
\hline Firm 7 & Karnataka & $\begin{array}{c}\text { New South Wales } \\
\text { and Victoria }\end{array}$ & 2 & Parent country & $\begin{array}{l}\text { Senior director } \\
\text { Senior manager }\end{array}$ & Onsite-offshore & One-way \\
\hline Firm 8 & Haryana & New South Wales & 1 & Parent country & Senior director & Onsite-offshore & One-way \\
\hline Firm 9 & West Bengal & New South Wales & 1 & Parent country & Senior director & Onsite-offshore & One-way \\
\hline Firm 10 & Karnataka & New South Wales & 2 & $\begin{array}{l}\text { Parent country, } \\
\text { Host country }\end{array}$ & $\begin{array}{l}\text { Senior director } \\
\text { Senior manager }\end{array}$ & Onsite-offshore & One-way \\
\hline Firm 11 & Tamil Nadu & New South Wales & 1 & Parent country & Senior director & Onsite-offshore & One-way \\
\hline Firm 12 & Maharashtra & $\begin{array}{l}\text { New South Wales, } \\
\text { Victoria and } \\
\text { Western Australia }\end{array}$ & 1 & Third country & Senior director & Onsite-offshore & One-way \\
\hline Firm 13 & Gujarat & New South Wales & 1 & Host country & Senior director & Onsite-offshore & One-way \\
\hline Firm 14 & Karnataka & Victoria & 1 & Parent country & Senior director & Onsite-offshore & One-way \\
\hline Firm 15 & Karnataka & Victoria & 1 & Parent country & Senior director & Onsite-offshore & One-way \\
\hline Firm 16 & Uttar Pradesh & $\begin{array}{c}\text { South Australia, } \\
\text { New South Wales, } \\
\text { Victoria and } \\
\text { Western Australia }\end{array}$ & 2 & $\begin{array}{l}\text { Parent country, } \\
\text { Host country }\end{array}$ & $\begin{array}{l}\text { Senior director } \\
\text { Senior manager }\end{array}$ & Onsite-offshore & Two-way \\
\hline
\end{tabular}




\section{INDIAN HEADQUARTERS}

Channel of

communication

between HQ \&

subsidiary

\section{AUSTRALIAN SUBSIDIARY OF INDIAN MNE}

Indian Expatriates in Senior Management Positions

Responsibilities: - liaise with headquarters.

- transfer HQ's best practices and culture to subsidiary.

\begin{tabular}{|l|c|c|}
\hline \multicolumn{3}{|c|}{ Knowledge Transfer Process } \\
\hline \multicolumn{1}{|c|}{ Socialization } & Externalization & Internalization \\
\hline $\begin{array}{l}\text { Expats sharing HQ's } \\
\text { best practices }\end{array}$ & $\begin{array}{c}\text { Transferring best practices and } \\
\text { know-how into documents }\end{array}$ & $\begin{array}{c}\text { coordination with } \\
\text { offshore team in HQ }\end{array}$ \\
\hline \multicolumn{3}{|c|}{$\begin{array}{c}\text { Host Country Nationals } \\
\text { Responsibility: }\end{array}$} \\
\hline
\end{tabular}

Figure 1: The onsite-offshore phenomenon and the role of expatriates in cross-border knowledge transfer in EMNEs 